\title{
The Effect of Outdoor Environmental Education Program on Secondary School Students' Knowledge, Attitude and Practices towards Water Pollution in Riverine Area of Ondo State
}

\author{
Samuel Olanrewaju Oladapo PhD \\ Adekunle Ajasin University \\ Akungba Akoko, Ondo State, Nigeria \\ E-mail: Lanree2007@gmail.com \\ Bright Ogunfunmilakin $P h D$ \\ Adekunle Ajasin University \\ Akungba Akoko, Ondo State, Nigeria \\ J.D. Kukuru PhD \\ Adekunle Ajasin University \\ Akungba Akoko, Ondo State, Nigeria
}

\begin{abstract}
Water pollution has been a major problem facing people living in riverine area all over Nigeria. This has become life threaten to majority of people living in the area as well as visitors to the area. A descriptive action research design was adopted foe the study and 3 instruments were developed for the collection of data. The population of the study comprises of all secondary school students in riverine area of Ondo State while 200 respondents were randomly selected from 10 schools 5 on the land and 5 on water. The questionnaire titled Environmental knowledge scale (EKS) Environmental Attitude scale (EAS) AND Environmental practice scale (EPS) were used to collect data for the study. Data generated were analyzed using descriptive statistics of mean, standard deviation and T. test. The result of the study shows that there was significant effect of treatment on participants' knowledge, attitude and practice towards water pollution and that location of school doesn't have significant effect on participants' behavior after the treatment based on the findings, it is therefore recommended that participation programme be encouraged at a level of education for solving environmental problems that is peculiar to any community.
\end{abstract}

Keywords: Ilaje/Ese odo, Water pollution, Riverine Area, Environmental Attitude

\section{Introduction}

Pollution can be said to be a human problem or one of the problems that emanates through human activities especially, while interacting with their environment .It is observed that before $19^{\text {th }}$ century Industrial Revolution, people lived more in harmony with their immediate environment. The spread of industrial revolution to all continents including Africa brought about different environmental pollution depending on the part of the earth one is residing. In Nigeria hence, we have land degradation in areas such as south west, south east and some part of SouthSouth Nigeria while water pollution in riverrine areas and desertification in the northern part of Nigeria are obvious. Ajitoni \& Oladapo(2014)

One of the major environmental pollution that people living in river rine areas are facing is water pollution and land degradation. In Ondo state, Ilaje and Eseodo are the two major local governments in the riverine areas, and are faced with water pollution. Water pollution occurs as a result of one or more substances built up in water to such an extent that they cause problem for human beings and animals. Most water pollution doesn't begin in the water itself it is as a result of human activities. Around 80 percent of ocean pollution enters our sea from the land. Virtually any human activity can have an effect on the quality of our water environment. For instance, when farmers fertilize the fields, 
the chemicals they use are gradually washed by rain into the ground water or surface water nearby. People most times see water body as a convenient place of dumping their waste.

Ilaje and Eseodo local governments are one of the most populated local governments in ondo state with a population figure of two hundred and seven thousand and fifty four $(207,054)$. It has a shore live covering about 280km (bent) the longest coastline in Nigeria crude oil producing areas. The local governments which were created by the Federal Government on Oct.1, 1996, consist of over six hundred towns and villages are being faced which include: land degradation, oil spilling and water pollution.

The government of Nigeria has several sources of funds for environmental protection activities. These include the ecological fund, through which $1 \%$ of the federation account is set aside for the amelioration of ecological problems such as soil erosion and flood control, desertification, drought and general environmental control (refuse, solid waste, water hyacinth, industrial waste). This amount was recently increased to $2 \%$ and paid into a Special Ecology Fund. In addition, the government has earmarked 3\% of the revenue accruing from crude oil in the country to tackle some ecological problems through the defunct Oil Minerals Producing Areas Development Commission (OMPADEC) and which has now metamorphosed to Niger-Delta Development Commission . Financial contributions from non-governmental organizations and the private sector also provide assistance for conservation efforts. Bilateral and multilateral financial assistance from such agencies like the World Bank, UNDP, UNEP, FAO, IUCN, UNICEF and ADB equally covers such problems as desertification control, capacity building and so on (Oladapo, 2012).

Environmental pollution is a function of the amount of toxic waste and pollutants or contaminant in the atmosphere. The amount and nature of greenhouse gas is space determine the environmental balance and climate change of a place. An increase or reduction of these gases in the atmosphere has adverse effects on the environmental challenges of a place. Greenhouse gases (GHGs) comes from a variety of sources e.g. (machines, automobiles, bush burning, waste, fertilizer, ashes, lava, stem). The manufacturing sectors and other related fields (fossil-coal, industrial waste, oil and natural gas) also constitute mainly to environmental pollution Thomas, (2009) and Cunningham and Cunningham, (2012).Furthermore, the use of fossil fuels to meet world's needs is another contributor to increase in greenhouse gases e.g. (carbon dioxide ( $\mathrm{Co} 2$ ), chlorofluorocarbon and methane).In Nigeria, the aegis of Environmental Rights Action (ERA) shown that about 1,000 oil spills are recorded annually in the Niger Delta region, the operations of the oil industries have endangered conflicts and impacted wetlands, water and sanitation problems (Ige, 2012). In Nigeria, the cardinal regions with heavy industrial concentration e.g. south-west, northcentral, and south-east are pruned to environmental pollution sand ecological challenges than any other parts of the country.

In south-south region for example where large oil and gas exploration takes place, the activities of environmental degradation, challenges and pollution has been on the rise in recent years.

The struggle for justice and mercy on the effects on environmental degradation, ecological challenges and environmental pollution has led to the death of seasoned icon and environmental activist Sir, Ken Sarowiwa among others. Of late, in October 19th 2013, oil spill from the platform of Mobil Oil Company in Eket Local Government Area in Akwa-Ibom state constitutes severe damage than good on the ecosystem and the communities. The people of these communities are yearning with the governments at the various levels to end this scourge and proffer ameliorable solutions on the negative impacts these activities have caused on the ecosystem and the lives of these citizenry. The implication of these is the consequence effects on food chain, water pollution and death of aquatic life etc. Furthermore, the explosion in January $16^{\text {th }} 2010$ claimed the lives of a harmful expatriate and many indigenous staff of the multinational company (Ige, 2012. These chemical parameters such as burning fuel (coal, petrol, wood) volcanoes (ash, aerosols) pool of water, respiration, decaying and putrefaction of plants and animals. The Carbon Gs, one of the atmospheric blankets of gases circulates in form of carbon dioxide to living organisms. Nitrogen and oxygen remain in fixed proportion throughout in the lower physics of the atmosphere and increase in heights over forty miles over the earth surface. Since the air thins with high-altitude (mountains over $3000 \mathrm{ft}$ or above $900 \mathrm{~m}$ ) the proportion of oxygen remains the same Ayo, (2009). The recent fire outbreak in Australia and the great storm in Philippines were attributed as natural phenomena and evolution of the ecosystem (Okpara, 2011). 


\section{Hypotheses}

The following hypotheses were tested at 0.05 level of significance

$\mathrm{Ho}_{1}$ :There is no significant main effect of treatment on participants'

(i) Knowledge on water pollution;

(ii)Attitude towards water pollution; and

(iii) Practices towards water pollution.

$\mathrm{Ho}_{2}$ : There is no significant main effect of location of Schools on participants'

(i) Knowledge on water polution;

(ii) Attitude towards water polution; and

(iii) Practices towards water polution.

$\mathrm{Ho}_{3}$ :There is no significant interaction effect of treatment and Schools' location on participants'

(i) Environmental knowledge;

(ii) Environmental attitude; and

(iii) Environmental practices.

\section{Scope of the study}

This study was designed to determine the impact of the programme on the environment-related knowledge, attitude and practices of 200 selected students in 10 schools in in Ilaje local government area of Ondo State.

\section{Research Design}

A descriptive action research design was adopted for the study. The study also adopted a pre-test, post-test, control group quasi- experimental design to determine the participants' environmental knowledge, attitude and practice on water pollution in Ondo State, Nigeria.

$\mathrm{Ho}_{1}: \quad$ There is no significant main effect of treatment on participants'

(i) Environmental knowledge;

(ii) Environmental attitude; and

(iii) Environmental practices.

Table 1: $t$ - test showing main effect of treatment on participants' environmental knowledge, attitude and practice

\begin{tabular}{|l|l|l|l|l|l|l|l|l|l|}
\hline Type & $\begin{array}{l}\text { Test } \\
\text { var. }\end{array}$ & Treatment & N & Mean & SD & t & df & P & Remark \\
\hline \multirow{3}{*}{ Control } & K & Pre & 25 & 8.62 & 1.12 & & & & \\
& & Post & 25 & 10.10 & 1.59 & -3.128 & 48 & .003 & S \\
\cline { 2 - 9 } & A & Pre & 25 & 37.10 & 4.55 & & & & \\
\hline
\end{tabular}




\begin{tabular}{|c|c|c|c|c|c|c|c|c|c|}
\hline & & Post & 25 & 37.42 & 3.73 & 1.115 & 48 & .011 & $\mathrm{~S}$ \\
\hline & $P$ & $\begin{array}{l}\text { Pre } \\
\text { Post }\end{array}$ & $\begin{array}{l}25 \\
25\end{array}$ & $\begin{array}{l}37.90 \\
38.45\end{array}$ & $\begin{array}{l}3.97 \\
4.43\end{array}$ & -0.446 & 48 & .026 & $\mathrm{~S}$ \\
\hline Experimental & K & $\begin{array}{l}\text { Pre } \\
\text { Post }\end{array}$ & $\begin{array}{l}25 \\
25\end{array}$ & $\begin{array}{l}9.45 \\
9.86\end{array}$ & $\begin{array}{l}1.90 \\
1.52\end{array}$ & -2.813 & 48 & .020 & $\mathrm{~S}$ \\
\hline & A & $\begin{array}{l}\text { Pre } \\
\text { Post }\end{array}$ & $\begin{array}{l}25 \\
25\end{array}$ & $\begin{array}{l}37.62 \\
38.34\end{array}$ & $\begin{array}{l}3.81 \\
4.69\end{array}$ & 1.603 & 48 & .010 & $\mathrm{~S}$ \\
\hline & $\mathrm{P}$ & $\begin{array}{l}\text { Pre } \\
\text { Post }\end{array}$ & $\begin{array}{l}25 \\
25\end{array}$ & $\begin{array}{l}38.48 \\
38.59\end{array}$ & $\begin{array}{l}5.30 \\
4.29\end{array}$ & 1.078 & 48 & .015 & $\mathrm{~S}$ \\
\hline
\end{tabular}

$* S=$ Significant, $\mathrm{K}=$ knowledge,$A=$ Attitude, $P=$ Practice

Table 1 revealed the main effect of treatment on participants' environmental knowledge, attitude and practice as follows; for control knowledge mean scores $8.62 \pm 1.12$ and $10.10 \pm 1.59$ for pre and post respectively with $(\mathrm{t}=$ $3.128, \mathrm{p}<0.05)$, attitude mean scores $37.10 \pm 4.55$ and $37.42 \pm 3.73$ for pre and post respectively with $(\mathrm{t}=1.115$, $\mathrm{p}<0.05)$ and practice mean scores $37.90 \pm 3.97$ and $38.45 \pm 4.43$ for pre and post respectively with $(\mathrm{t}=-0.446$, $\mathrm{p}<0.05)$. While for experimental knowledge mean scores $9.45 \pm 1.90$ and $9.86 \pm 1.52$ for pre and post respectively with $(\mathrm{t}=-2.813, \mathrm{p}<0.05)$, attitude mean scores $37.62 \pm 3.81$ and $38.34 \pm 4.69$ for pre and post respectively with $(\mathrm{t}=1.603$, $\mathrm{p}<0.05)$ and practice mean scores $38.48 \pm 5.30$ and $38.59 \pm 4.29$ for pre and post respectively with $(t=1.078, p<0.05)$. These results revealed a significant main effect of treatment on participants' knowledge, attitude and practice of environmental.

$\mathrm{Ho}_{2}$ : There is no significant main effect of location of schools on participants'

(i) environmental knowledge;

(ii) environmental attitude; and

(iii) environmental practices.

Table 2: $\mathbf{t}$ - test showing main effect of location on participants' environmental knowledge, attitude and practice

\begin{tabular}{|l|l|l|l|l|l|l|l|l|l|}
\hline Type & $\begin{array}{l}\text { Test } \\
\text { var. }\end{array}$ & Location & $\mathbf{N}$ & Mean & SD & t & df & P & Remark \\
\hline \multirow{3}{*}{ Ctrl } & K & Land & 25 & 9.32 & 1.79 & & & & \\
& & Riverine & 25 & 9.64 & 1.82 & -.625 & 48 & .535 & NS \\
\cline { 2 - 10 } & A & Land & 25 & 35.40 & 1.84 & & & & \\
& Riverine & 25 & 38.92 & 4.86 & -3.388 & 48 & .001 & S \\
\cline { 2 - 10 } & P & Land & 25 & 37.44 & 4.17 & & & & \\
\hline \multirow{2}{*}{ Exptal } & Riverine & 25 & 39.00 & 4.19 & 1.318 & 48 & .194 & NS \\
\hline
\end{tabular}




\begin{tabular}{|l|l|l|l|l|l|l|l|l|l|}
\hline & A & Land & 25 & 36.96 & 3.84 & & & & NS \\
\cline { 3 - 9 } & & Riverine & 25 & 39.12 & 4.29 & -1.876 & 48 & .067 & \\
& & Land & 25 & 38.44 & 5.34 & & & NS \\
\hline
\end{tabular}

$* S=$ Significant,$N S=$ Not significant, $K=$ knowledge, $A=$ Attitude, $P=$ Practice

Table 2 revealed the main effect of location of school on participants' environmental knowledge, attitude and practice as follows; for control knowledge mean scores $9.32 \pm 1.79$ and $9.64 \pm 1.82$ for land and riverine locations respectively with $(\mathrm{t}=-0.625, \mathrm{p}>0.05)$, attitude mean scores $35.40 \pm 1.84$ and $38.92 \pm 4.86$ for land and riverine locations respectively with $(\mathrm{t}=-3.388, \mathrm{p}<0.05)$ and practice mean scores $37.44 \pm 4.17$ and $39.00 \pm 4.19$ for land and riverine respectively with $(\mathrm{t}=1.318, \mathrm{p}>0.05)$. While for experimental knowledge mean scores $9.20 \pm 1.65$ and $10.04 \pm 1.78$ for land and riverine respectively with $(t=1.733, p>0.05)$, attitude mean scores $36.96 \pm 3.84$ and $39.12 \pm 4.29$ for land and riverine respectively with $(t=-1.876, p>0.05)$ and practice mean scores $38.44 \pm 5.34$ and $38.64 \pm 4.42$ for land and revirine respectively with $(t=0.144, p>0.05)$. These results revealed that no significant main effect of location on participants' knowledge, attitude and practice of environmental.

$\mathrm{Ho}_{3}: \quad$ There is no significant interaction effect of treatment and schools' location on participants'

(i) Environmental knowledge;

(ii) Environmental attitude; and

(iii) Environmental practices.

Table 3: $t$ - test showing the interaction effect of treatment and school location on participants' environmental knowledge, attitude and practice

\begin{tabular}{|c|c|c|c|c|c|c|c|c|c|}
\hline Treatment & $\begin{array}{l}\text { Test } \\
\text { var. }\end{array}$ & Location & $\mathbf{N}$ & Mean & SD & $\mathbf{t}$ & df & $\mathbf{P}$ & Remark \\
\hline \multirow[t]{3}{*}{ Pre } & $\mathrm{K}$ & $\begin{array}{l}\text { Land } \\
\text { Riverine }\end{array}$ & $\begin{array}{l}50 \\
50\end{array}$ & $\begin{array}{l}8.88 \\
10.00\end{array}$ & $\begin{array}{l}1.44 \\
1.76\end{array}$ & -3.483 & 98 & .001 & $\mathrm{~S}$ \\
\hline & A & $\begin{array}{l}\text { Land } \\
\text { Riverine }\end{array}$ & $\begin{array}{l}50 \\
50\end{array}$ & $\begin{array}{l}35.52 \\
38.28\end{array}$ & $\begin{array}{l}2.31 \\
4.86\end{array}$ & -3.630 & 98 & .000 & S \\
\hline & $\mathrm{P}$ & $\begin{array}{l}\text { Land } \\
\text { Riverine }\end{array}$ & $\begin{array}{l}50 \\
50\end{array}$ & $\begin{array}{l}37.94 \\
39.20\end{array}$ & $\begin{array}{l}4.33 \\
4.08\end{array}$ & 1.498 & 98 & .037 & S \\
\hline \multirow{3}{*}{ Post } & $\mathrm{K}$ & $\begin{array}{l}\text { Land } \\
\text { Riverine }\end{array}$ & $\begin{array}{l}50 \\
50\end{array}$ & $\begin{array}{l}9.12 \\
9.98\end{array}$ & $\begin{array}{l}1.26 \\
1.64\end{array}$ & -2.950 & 98 & .004 & $S$ \\
\hline & $\mathrm{A}$ & $\begin{array}{l}\text { Land } \\
\text { Riverine }\end{array}$ & $\begin{array}{l}50 \\
50\end{array}$ & $\begin{array}{l}36.78 \\
39.08\end{array}$ & $\begin{array}{l}4.05 \\
4.28\end{array}$ & -2.759 & 98 & .007 & $\mathrm{~S}$ \\
\hline & $\mathrm{P}$ & $\begin{array}{l}\text { Land } \\
\text { Riverine }\end{array}$ & $\begin{array}{l}50 \\
50\end{array}$ & $\begin{array}{l}38.24 \\
38.56\end{array}$ & $\begin{array}{l}4.79 \\
4.40\end{array}$ & 1.348 & 98 & .029 & $S$ \\
\hline
\end{tabular}

$* S=$ Significant,$N S=$ Not significant,$K=$ knowledge, $A=$ Attitude, $P=$ Practice 
Table 3 revealed the interaction effect of treatment and school location on participants' environmental knowledge, attitude and practice as follows; for land knowledge mean scores $8.88 \pm 1.44$ and $10.00 \pm 1.76$ for land and riverine location respectively with $(\mathrm{t}=-3.483, \mathrm{p}<0.05)$, attitude mean scores $35.52 \pm 2.31$ and $38.28 \pm 3.73$ for land and riverine location respectively with $(\mathrm{t}=-3.630, \mathrm{p}<0.05)$ and practice mean scores $37.94 \pm 4.33$ and $39.20 \pm 4.08$ for land and riverine location respectively with $(\mathrm{t}=-1.498, \mathrm{p}<0.05)$. While for experimental knowledge mean scores 9.12 \pm 1.12 and $9.98 \pm 1.64$ for land and riverine location respectively with $(t=-2.950, p<0.05)$, attitude mean scores $36.78 \pm 4.05$ and $39.08 \pm 4.28$ for land and riverine location respectively with $(\mathrm{t}=-2.759, \mathrm{p}<0.05)$ and practice mean scores $38.24 \pm 4.79$ and $38.56 \pm 4.40$ for land and riverine location respectively with $(t=1.348, p<0.05)$. These results revealed a significant interaction effect of treatment and school location on participants' knowledge, attitude and practice of environmental

\section{Discussion}

The result presented in table 1 mainly revealed the effects of the treatment on participants' environmental knowledge, attitude and practice and the result revealed significant main effect of the treatment participants' knowledge, attitude and practices towards water pollution. The treatment changes the participant negative practice towards water pollution. This is finding is in line with the findings of Oladapo (2012) in which it was revealed that participants learn when they participate in finding solution to issues that concern them.

The result presented in table 2, which looked into the effect of location on participants' knowledge, attitude and practice towards water pollution. The results revealed that there is no significant main effect of location on participants' knowledge, attitude and practice towards water pollution. This finding is in line with the finding of Akintola, (2004) in which it is revealed that locations are most times determinant of learning outcome.

Findings in table 3 show the interaction effect of treatment and school location on participants' environmental knowledge, attitude and practice. The result revealed a significant interaction effect of treatment and school location on participants' knowledge, attitude and practice towards water pollution. The result shows that students in riverine location didn't perform better than those on the land.

\section{References}

Ajiboye, J.O. and Ajitoni, S.O. 2008. Effects of full and quasi-participatory learning strategies on Nigeria secondary students'; environmental knowledge:Implications for classroom practice. International Journal of Environmental and Science Education, 3(2).

Akintola, B.A. 2004. Environmental information requirement: Utilization and dissemination in solid waste management organizations in Oyo State,Nigeria. Unpublished Ph.D thesis Faculty of Education, University of Ibadan, Nigeria.

Gbademosi, V.T. 2012. Effect of service learning and educational trips instructional strategies on primary school pupils' environmental literacy in Social studies in Oyo State, Nigeria. Unpublished Ph.D thesis Faculty of Education, University of Ibadan, Nigeria.

Ogundipe, R. 2006. Introduction to environment issues, causes, effects, and Solution. Ikofa Commercial Press Ltd, Shomolu, Lagos.

Oladapo, S.O. 2012. Effect of a participatory environmental education programme On traders;' Knowledge, attitude and practices in waste management in Oyo State, Nigeria. Unpublished Ph.D thesis, University of Ibadan, Ibadan.

Sridhar, M.K.C. 1986. Heavy metal contests of some solid waste in Ibadan, Nigeria. Water, air and soil pollution (USA) 29:51-56.

\section{Copyrights}

Copyright for this article is retained by the author(s), with first publication rights granted to the journal. This is an open-access article distributed under the terms and conditions of the Creative Commons Attribution license (http://creativecommons.org/licenses/by/4.0/). 